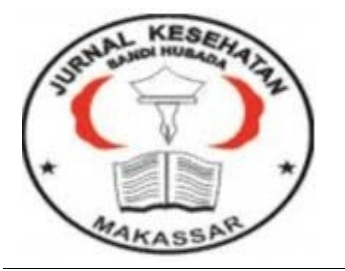

\author{
Jurnal Ilmiah Kesehatan Sandi Husada \\ hhttps://akper-sandikarsa.e-journal.id/JIKSH \\ Vol 11, No, 1, Juni 2020, pp;403-412 \\ p-ISSN: 2354-6093 dan e-ISSN: 2654-4563 \\ DOI: $10.35816 /$ jiskh.v10i2.313
}

\title{
Efek Penambahan Nanokitosan 1\% Kedalam Berbagai Konsentrasi Ekstrak Kulit Kelengkeng Streptococcus Mutans
}

Effect of 1\% Nanocitosan Addition to Various Concentrations of Streptococcus Mutans Longan Skin Extract

\section{Titania Aurely Tandra1, Sabrina Khairunissa' ${ }^{2}$, Mellisa Sim ${ }^{3}$, Florenly ${ }^{4}$ \\ 1,2Program Studi Kedokteran Gigi, Universitas Prima Indonesia \\ 3,4Fakultas Kedokteran gigi, Universitas Prima Indonesia}

\begin{tabular}{l}
\hline \multicolumn{1}{c}{ Artikel info } \\
\hline Artikel history: \\
Received; 10 Mei 2020 \\
Revised: 13 Mei 2020 \\
Accepted; 14 Mei 2020
\end{tabular}

Abstrak

Kulit Kelengkeng (Dimocarpus longan Lour) mengandung senyawa flavonoid, glikosida, saponin dan tannin, sehingga memiliki kapasitas antibakteri.Nanokitosan 1\% yang dicampurkan ke dalam ekstrak tumbuhan mampu meningkatkan daya hambat pertumbuhan bakteri di rongga mulut. Penelitian ini bertujuan untuk membandingkan efektivitas ekstrak kulit kelengkeng (Dimocarpus longan Lour) yang ditambahkan nanokitosan 1\% dalam menghambat Streptococcusmutans pada berbagai konsentrasi, yaitu 40\%, 60\% dan 80\%. Pembuatan ekstrak kulitkelengkeng dilakukan dengan metode maserasi dan dibuat dengan konsentrasi 40\%, 60\% dan 80\%. Sedangkan nanokitosan 1\% dibuat dengan metode gelas ionik. Kedua bahan dicampur dalam rasio 1:1, dan diuji efektivitas daya hambatnya dengan metode difusi cakram. Hasil penelitian menunjukkan nilai mean dan standar deviasi ekstrak kulit kelengkeng pada konsentrasi 40\%, 60\% dan 80\% dengan nanokitosan $1 \%$ adalah $6,86 \pm 0,471 \mathrm{~mm} ; 7,62 \pm 0,533 \mathrm{~mm}$ dan 8,53 $\pm 0,395 \mathrm{~mm}$. Daya hambat dengan diameter $>7 \mathrm{~mm}$ menunjukkan antibakteri kekuatan sedang. Uji Shapiro-Wilk membuktikan bahwa data terdistribusi normal. Hasil analisis statistik dengan one way Analysis of Variance (ANOVA) menunjukkan ekstrak kulit kelengkeng (Dimocarpus longan Lour) dicampurkan dengan nanokitosan 1\% paling efektif dalam menghambat Streptococcus mutans pada konsentrasi $80 \%$, di mana $p=0,000(0<0,05)$. Hal ini disebabkan adanya peningkatan konsentrasi senyawa fitokimia.

\begin{abstract}
Longan skin (Dimocarpus longan Lour) contains flavonoid compounds, glycosides, saponins and tannins, so it has an antibacterial capacity. 1\% Nanocitosan mixed into plant extracts can increase the inhibitory growth of bacteria in the oral cavity. This study aims to compare the effectiveness of longan skin extract (Dimocarpus longan Lour) added 1\%
\end{abstract}


nanocitosan in inhibiting Streptococcusmutans at various concentrations, namely 40\%, 60\% and 80\%. Longan skin extract is made by maceration method and made with a concentration of 40\%, 60\% and $80 \%$. Whereas 1\% nanocitosan is made by the ionic glass method. The two ingredients were mixed in a ratio of 1: 1, and the effectiveness of inhibition was tested by the disk diffusion method. The results showed the mean and standard deviation of longan skin extract at concentrations of $40 \%, 60 \%$ and $80 \%$ with $1 \%$ nanocitosan was $6.86 \pm 0.471 \mathrm{~mm} ; 7.62 \pm 0.533 \mathrm{~mm}$ and $8.53 \pm$ $0.395 \mathrm{~mm}$. Inhibition with a diameter $>7 \mathrm{~mm}$ indicates medium strength antibacterial. The Shapiro-Wilk test proves that the data are normally distributed. Statistical analysis with one way Analysis of Variance (ANOVA) showed longan skin extract (Dimocarpus longan Lour) mixed with 1\% nanocitosan most effective in inhibiting Streptococcus mutans at $80 \%$ concentration, where $p=0,000(0<0.05)$. This is due to an increase in the concentration of phytochemical compounds.

Keywords:

Longan peel

(Dimocarpus longan

Lour);

Nanochitosan;

Streptococcus mutans;
Coresponden author:

Email: ly@unprimdn.ac.id

artikel dengan akses terbuka dibawah lisensi CC BY -4.0

\section{Pendahuluan}

(Nindya Cahyaningrum, 2017) melaporkan bahwa banyak kejadian penyakit didalam rongga mulut yang terjadi yaitu penyakit periodontal dan karies. Karies adalah kejadian dimana rusaknya struktur jaringan keras pada gigi yang meliputi enamel, dentin dan cementum(Widayati, 2014). (Fitrianda, 2016) mengatakan terjadinya karies berawal dengan terjadinya proses demineralisasi jaringan keras pada gigi dan rusaknya elemen organik pada gigi sehingga bakteri invasi ke bagian dalam gigi dan mencapai pulpa.

Bakteri merupakan salah satu faktor penyebab karies. Rongga mulut manusia memiliki banyak jenis bakteri, salah satu diantaranya adalah Streptococcus mutans. (Bontjura, Waworuntu and Siagian, 2015) dalam penelitiannya mengatakan karies yang menempel dibagian lapisan terluar gigi, menghasilkan asam serta melarutkan enamel sehingga terjadi proses demineralisasi yang disebabkan bakteri Streptococcus mutans. Menurut (Gartika and Satari, 2013) Streptococcus mutans ialah bakteri gram positif, bersifat anaerob, dengan bentuk bulat berukuran 0,5-0,7 mikron yang dapat membentuk rantai selama pertumbuhannya. Pada penelitian yang dilakukan (Nugraha, 2008) menyimpulkan bahwa bakteri Streptococcus mutans tumbuh secara optimal pada suhu $18-40^{\circ} \mathrm{C}$ dan sering ditemukan pada rongga mulut manusia. (Di and Dangin, 2017) dalam penelitiannya mengatakan Streptococcus mutans bersifat asidogenik karena menghasilkan asam dan dapat mendukung bakteri lain melarutkan enamel gigi dan proses demineralisasi dimulai.

Dalam penelitiannya, (Angela, 2005) menyatakan bahwa pencegahan pada karies umumnya terdiri atas dua yaitu secara mekanik dan kimiawi. Pada pencegahan mekanik, biasanya dilakukan penyikatan gigi secara tepat dan teratur (Panjaitan, 1997). Dalam penelitian (Warganegara and Restina, 2016) pencegahan kimiawi karies diirawat dengan dengan menggunakan tanaman herbal yaitu getah jarak yang memiliki kandungan yang dapat menghambat pertumbuhan dan perkembangan bakteri. (Oktora et al., 2006), dalam penelitiannya mengatakan keuntungan dalam penggunaan bahan herbal antara lain 
mudah didapat, murah, aman digunakan. Pada penelitian yang dilakukan (Qulbi, 2017), mengatakan bahwa terdapat 12 jenis tumbuhan-tumbuhan yang memiliki potensi dalam mengobati karies dimana tumbuhan yang memiliki presentase tertinggi adalah belimbing wuluh 22\%, pinang 12\%, dan daun sirih 30\%. Penelitian (Kawengian, Wuisan and Leman, 2017) tentang ekstrak daun kucai berbagai konsentrasi $2 \%, 4 \%$ dan $8 \%$, terhadap pengujian zona hambat pertumbuhan Streptococcus mutans, dimana konsentrasi $8 \%$ paling efektif untuk menghambat bakteri Streptococcus mutans.

Pada penelitian (Fasina et al., 2015) ditemukan bahwa kulit dan biji kelengkeng mengandung flavonoid, saponin dan tanin. Flavonoid berperan sebagai yang dapat merusak bakteri dengan membuat substansi kompleks sehingga dapat mengganggu keseimbangan sel bakteri tersebut dan rusaknya permeabilitas dinding sel bakteri. Saponin sebagai antibakteri yaitu melalui hidrogen yang terikat, membentuk substansi kompleks membran sel, dan merusak pertahanan sel bakteri sehingga sel rusak kemudian bakteri mati. (Wulandari, Utami and Hartanti, 2009). Menurut (Ngajow, Abidjulu and Kamu, 2013), Tanin berperan karena merusak membran sel dengan mengkerutkan dinding sel bakteri, sehingga sel tidak dapat bertumbuh dan pada akhirnya sel bakteri mati. Dalam penelitian (Santi, Muhtadi and Indrayudha, 2011) menyatakan jika konsentrasi ekstrak semakin tinggi maka senyawa yang dapat menghambat pertumbuhan dan perkembangan bakteri semakin banyak. Selain sebagai antibakteri, senyawa fitokimia yang terdapat dalam kulit kelengkeng juga berpotensi sebagai pelindung organ ginjal (Florenly et al., 2016).

Kitosan adalah biopolymer alami yang dapat disintesis dari kulit krustasea seperti kepiting, udang, dan lobster yang mengandung kitin (Citrowati, Satyantini and Mahasri, 2019) Saat ini kitosan digunakan dalam berbagai bidang industri modern dan melakukan modifikasi secara kimia dan fisik. (Suwarda and Maarif, 2013), dalam penelitiannya memodifikasi fisik kitosan dengan merubah ukuran partikel menjadi partikel yang lebih kecil sehingga menjadi bentuk nanopartikel, hasil yang didapat menunjukkan bahwa nanopartikel lebih reaktif dan daya penyerapan lebih tinggi dibanding dengan material lain. Menurut (Wardaniati and Setyaningsih, 2009), kitosan memiliki potensi membunuh bakteri, dikarenakan kitosan mempunyai enzim lysosim yang dapat membuat bakteri tumbuh dengan sangat lambat.

Nanokitosan merupakan kitosan dengan ukuran partikel 100-400 nm (Uday Raj et al., 2015). Pada penelitian (Qudsi et al., 2016) mengenai perbedaan efek nanokitosan sebagai antibakteri dilihat dari konsentrasi dimana besarnya konsentrasi nanokitosan mempengaruhi efek antibakterinya juga semakin besar dengan zona hambat terbesar ditunjukkan pada konsentrasi 1\%. Hal ini disebabkan muatan positif kitosan berinteraksi dengan muatan negatif di permukaan bakteri. Bakteri Streptococcus mutans adalah bakteri aerob bergram positif, asam teikoat berinteraksi dengan muatan positif kitosan pada permukaan sel mengganggu fungsi membran bakteri (Rafat, Philip and Muniandy, 2010). Nanokitosan 1\% merupakan konsentrasi efektif yang dapat dicampurkan ke dalam ekstrak tumbuhan dan berpotensi untuk meningkatkan daya hambat pertumbuhan bakteri Streptococcus mutans. Hal tersebut sesuai penelitian (Rismana et al., 2014) bahwa campuran nanokitosan dan ekstrak kulit buah manggis dalam menghambat bakteri Propionibacterium acnes. Pada konsentrasi nanokitosan 1\% - 2\% hasilnya lebih baik dibanding ekstrak kulit buah manggis tunggal karena nanokitosan sebagai bahan matriks untuk membawa dan menghantarkan ekstrak sehingga aktivitas dalam menghambat antibakteri lebih tinggi (Ismiyati et al., 2017).

Berdasarkan latar belakang diatas didapati berbagai penelitian yang menunjukkan bahwa kulit kelengkeng dan nanokitosan mempunyai daya hambat antibakteri, namun belum ada penelitian yang menggabungkan kedua bahan yang akan digunakan pada penelitian ini. 
Maka peneliti tertarik untuk meneliti bagaimana daya hambat ekstrak kulit kelengkeng (Dimocarpus longan Lour) yang ditambahkan nanokitosan $1 \%$ terhadap bakteri Streptococcus mutans lebih efektif pada konsentrasi 40\%, 60\% atau 80\%.

\section{Metode}

Sample kulit kelengkeng diekstraksi menggunakan metode maserasi dengan merendam dalam etanol 95\% kemudian diaduk selama 24 jam selama lima hari. Kertas saring digunakan dengan bantuan pompa vacum untuk menyaring ekstrak sehingga didapatkan filtrat. Filtrat dikumpul lalu diaduk dengan menggunakan rotary evaporator dengan suhu $40^{\circ} \mathrm{C}$. Selanjutnya filtrat yang tersisa diuapkan dengan beaker glass di dalam inkubator. Ekstrak kental dan pekat yang telah didapatkan dibuat menjadi tiga konsentrasi yaitu 40\%,60\% dan 80\%. Ekstrak kental dan pekat tiap konsentrasi dilakukan pengecekan fitokimia untuk menentukan kandungan senyawa pada ekstrak etanol kulit kelengkeng yang terdiri dari uji alkaloid, flavonoid, steroid, saponin, triterpen, saponin, tannin, dan glikosida.

Pembuatan sample nanokitosan mengunakan metode gelas ionic. Timbang serbuk kitosan sebanyak 0,5 g larutkan kedalam $50 \mathrm{~mL}$ asam asetat 1\%, diaduk selama 8 jam menggunakan magnetic stirrer. Kemudian disonikasikan selama 40 menit. Timbang Natrium Tripolifosfat sebanyak 0,1 g dilarutkan kedalam $100 \mathrm{~mL}$ akuades, diaduk selama 8 jam dengan menggunakan magnetic stirrer dan disonikasi selama 40 menit. Campurkan larutan Natrium Tripolifosfat 0,1\% dan larutan kitosan 1\% dengan perbandingan $2: 1$, menggunakan spuit $1 \mathrm{~mL}$ dengan kecepatan 15 tetes/menit. Aduk larutan selama 8 jam dengan magnetic stirrer dan disonikasi selama 45 menit (Hanutami and Budiman, 2017). Sample nanokitosan 1\% dalam bentuk cair dianalisis ukurannya dengan alat PSA (Particle Size Analysis) menggunkan metode dynamic light scattering dan dispersi cair.

Sterilkan alat terlebih dahulu dalam autoklaf selama 15 menit. Uji aktivitas antibakteri menggunakan metode difusi cakram. Bakteri Streptococcus mutans diremajakan dan diinokulasi pada media agar dengan metode zig-zag. Letakkan cakram kertas diatas media menggunakan pinset diatas permukaan media dengan jarak $15 \mathrm{~mm}$ dari tepi cawan dengan jarak antara titik tengah cakram sekitar $60 \mathrm{~mm}$. Tetesin ekstrak kulit kelengkeng 40\%, 60\%,80\%, nanokitosan 1\% dan kombinasi diulangi sebanyak 6 kali. Inkubasi dengan suhu $37^{\circ} \mathrm{C}$ selama 24 jam. Lakukan pengukuran zona hambat diatas coloni counter dengan jangka sorong pada media agar.

Uji statistik dalam penelitian ini untuk menguji dari 3 grup konsentrasi ekstrak kulit kelengkeng untuk menentukan kelompok mana yang lebih efektif menghambat bakteri Streptococcus mutans, setelah ditambahkan nanokitosan 1\%. Data yang diperoleh diuji distribusinya menggunakan uji normalitas Shapiro-Wilk. Data yang berkontribusi normal diuji one way Analysis of Variance (ANOVA) untuk menganalisa signifikasi sehingga peneliti dapat mengetahui perbedaan rata-rata antara grup perlakuan. 


\section{Hasil Dan Pembahasan}

Tabel 1. Hasil pengujian fitokimia pada ekstrak kulit kelengkeng (Dimocarpus longan Lour) secara kualitatif senyawa yang terdapat dalam ekstrak Kulit Kelengkeng

\begin{tabular}{llll}
\hline No. & Metabolit Sekunder & Pereaksi & Hasil \\
\hline 1 & Alkaloid & $\begin{array}{l}\text { Dragendrof } \\
\text { Bouchardat } \\
\text { Meyer }\end{array}$ & - \\
& & Serbuk $\mathrm{Mg}+\mathrm{Amil}_{\text {Alkohol }+\mathrm{HCl}_{\mathrm{p}}}$ & - \\
\hline 2 & Flavonoid & Molish $+\mathrm{H}_{2} \mathrm{SO}_{4}$ & + \\
\hline 3 & Glikosida & Air panas / dikocok & + \\
\hline 4 & Saponin & FeCL & + \\
\hline 5 & Tanin & Lieberman - Bourchat & - \\
\hline 6 & Triterpen/Steroid & & \\
\hline
\end{tabular}

Sumber: data primer

Tabel 2. Hasil Uji PSA (Particle Size Analyzer) nanokitosan 1\%

\begin{tabular}{ccccc}
\hline Nama Sampel & Parameter & Satuan & Hasil Uji & Metode Uji \\
\hline Nanokitosan & Nanopartikel & $\mathrm{Nm}$ & 101,5 & Dynamic light scattering \\
\cline { 2 - 5 } $1 \%$ & & $\mathrm{Nm}$ & 93,71 & Dispersi cair \\
\hline
\end{tabular}

Sumber: data primer

Tabel 3. Uji Antibakteri Diameter Zona Hambat Campuran Ekstrak Kulit Kelengkeng (Dimocarpus longan Lour) dengan Nanokitosan 1\% dalam Menghambat Pertumbuhan Streptococcus mutans

\begin{tabular}{|c|c|c|c|c|c|c|c|c|c|}
\hline \multirow[t]{2}{*}{ Bahan Uji } & \multirow{2}{*}{ Konsentrasi } & \multicolumn{6}{|c|}{ Replikasi (mm) } & \multirow{2}{*}{$\begin{array}{l}\text { Mean } \\
(\mathrm{mm})\end{array}$} & \multirow[t]{2}{*}{ SD } \\
\hline & & 1 & 2 & 3 & 4 & 5 & 6 & & \\
\hline $\begin{array}{l}\text { Campuran } \\
\text { Nanokitosan }\end{array}$ & $40 \%$ & 6,2 & 7,15 & 6,33 & 7,3 & 7,1 & 7,1 & 6,86 & 0,471 \\
\hline 1\% dengan & $60 \%$ & 7,28 & 8,48 & 7,05 & 8,05 & 7,45 & 7,45 & 7,62 & 0,533 \\
\hline $\begin{array}{l}\text { Ekstrak Kulit } \\
\text { Kelengkeng }\end{array}$ & $80 \%$ & 8,2 & 9,0 & 9,05 & 8,35 & 8,45 & 8,15 & 8,53 & 0,395 \\
\hline
\end{tabular}

Sumber: data primer

Tabel 4. Diameter Zona Hambat berbagai konsentrasi Ekstrak Murni Kulit Kelengkeng (Dimocarpus longan Lour) dan Nanokitosan 1\% dalam Menghambat Pertumbuhan Streptococcus mutans

\begin{tabular}{lccc}
\hline \multicolumn{1}{c}{ Bahan Uji } & Konsentrasi & $\begin{array}{c}\text { Diameter Zona } \\
\text { Hambat (mm) }\end{array}$ & SD \\
\hline Ekstrak & $40 \%$ & 6,25 & \\
Kulit & $60 \%$ & 7,10 & 0,000 \\
Kelengkeng & $80 \%$ & 8,25 & \\
\hline Nanokitosan & $1 \%$ & 7,45 & \\
\hline
\end{tabular}

Sumber: data primer 
Tabel 5. Hasil Uji One Way ANOVA Campuran Ekstrak Kulit Kelengkeng (Dimocarpus longan Lour) dengan Nanokitosan 1\% dalam Menghambat Pertumbuhan Streptococcus mutans

\begin{tabular}{lcccc}
\hline \multicolumn{1}{c}{ Bahan Uji } & Konsentrasi & Mean & SD & p value \\
\hline Campuran & $40 \%$ & 6,86 & 0,471 & \\
Nanokitosan & $60 \%$ & 7,62 & 0,533 & $0,000^{*}$ \\
$1 \% \quad$ dengan & $80 \%$ & 8,53 & 0,395 & \\
Ekstrak Kulit & & & & \\
Kelengkeng & & & & \\
Sumber: data primer &
\end{tabular}

Tabel 6. Hasil Uji One Way ANOVA berbagai konsentrasi Ekstrak murni Kulit Kelengkeng (Dimocarpus longan Lour) dan Nanokitosan 1\% dalam Menghambat Pertumbuhan Streptococcus mutans.

\begin{tabular}{lllll}
\hline \multicolumn{1}{c}{ Bahan Uji } & Konsentrasi & $\begin{array}{c}\text { Zona hambat } \\
(\mathbf{m m})\end{array}$ & SD & p value \\
\cline { 1 - 3 } Ekstrak & $40 \%$ & 6,25 & 0,000 & \multirow{2}{*}{$0,000^{*}$} \\
Kulit & $60 \%$ & 7,10 & & \\
Kelengkeng & $80 \%$ & 8,25 & 0,000 & \\
\cline { 1 - 2 } Nanokitosan & $1 \%$ & 7,45 & &
\end{tabular}

Sumber: data primer
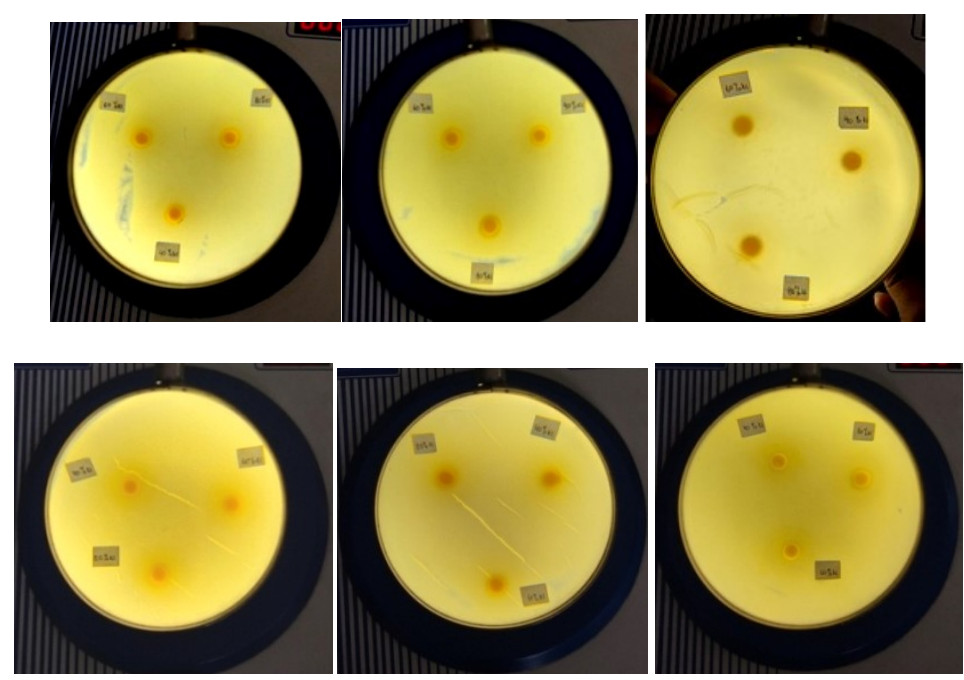

Gambar 1. Hasil Zona Hambat Campuran Ekstrak Kulit Kelengkeng (Dimocarpus longan Lour) dengan Nanokitosan 1\% dalam Menghambat Pertumbuhan Streptococcus mutansdengan 6 kali pengulangan 


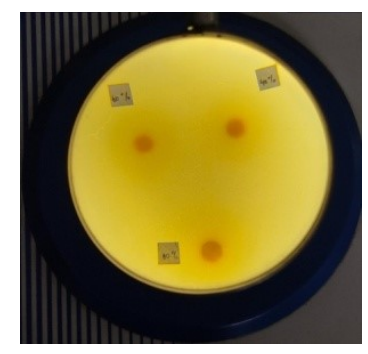

\section{Gambar 2. Hasil Zona Hambat kontrol positif Ekstrak murni Kulit Kelengkeng (Dimocarpus longan Lour) konsentrasi 40\%, 60\% dan 80\% dalam Menghambat Pertumbuhan Streptococcus mutans}

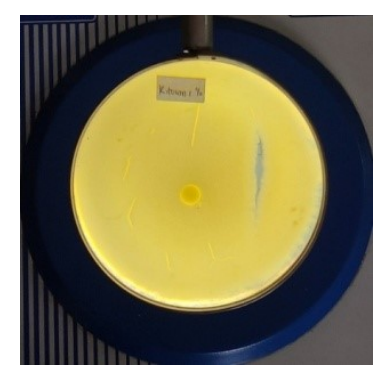

\section{Gambar 3. Hasil Zona Hambat kontrol positif Nanokitosan 1\% dalam Menghambat Pertumbuhan Streptococcus mutans}

Penelitian ini menggunakan kulit kelengkeng dengan spesies Dimocarpus longan Lour yang diekstraksi dan dibagi menjadi beberapa konsentrasi yaitu 40\%,60\% dan 80\%. Hasil uji fitokimia menunjukkan senyawa yang terdapat dalam ekstrak kulit kelengkeng pada penelitian ini adalah flavonoid, saponin, glikosida, dan tanin yang mempunyai potensi merusak bakteri. Hasil tersebut sesuai dengan penelitian (Fasina et al., 2015), yang melakukan penelitian bagaimana aktivitas antimikroba pada ekstrak kulit, daun, dan biji kelengkeng dimana hasil ekstraknya terbukti mengandung senyawa yang bermanfaat sebagai antimikroba. Kulit kelengkeng selain bermanfaat sebagai antibakteri, juga berpotensi untuk menyerap bakteri pada cairan dengan $\mathrm{pH}$ rendah sehingga berpotensi sebagai bahan kumur. (Florenly et al., 2015) dalam penelitiannya memperlihatkan struktur permukaan kulit kelengkeng yang poreus dan bergelombang, serta pada $\mathrm{pH}$ rendah berpotensi maksimal dalam menyerap logam aktif pada larutan yang terkontaminasi.

Selain itu penelitian ini juga menggunakan kitosan. Menurut (Zuniarto, 2019), kitosan memiliki aktivitas antibakteri, berspektrum luas, dan memiliki tingkat perusak yang rendah. Berdasarkan uji PSA (Particle Size Analyzer) didapatkan ukuran nanokitosan 1\% dengan menggunakan metode Dynamic light scattering yaitu 101,8 $\mathrm{nm}$ dan ukuran nanokitosan $1 \%$ dengan menggunakan metode dispersi cair adalah 0,09371 $\mu \mathrm{m}$. Hasil ini sama dengan penelitian (Abdassah, 2009), dimana dalam penelitiannya mengatakan bahwa nanopartikel merupakan partikel berukuran 1-100 nanometer.

Dari ketiga grup perlakuan hasil yang didapatkan dari penelitian ini mempunyai efek merusak bakteri Streptococcus mutans dengan diameter zona hambat ekstrak kulit kelengkeng 40\%,60\% dan 80\% - Nanokitosan adalah 6,86 mm; 7,62 mm; 8,53 mm. Hal ini menunjukkan bahwa tingginya konsentrasi ekstrak kulit kelengkeng (Dimocarpus longan Lour) maka efek terhadap antibakteri ikut meningkat. Menurut penelitian (Pelzhar., 1988) menyimpulkan bahwa kekuatan bahan antibakteri dipengaruhi oleh konsentrasi suatu 
bahan antibakteri. Sesuai dengan penelitian (Sharma et al., 2009), campuran nanokitosan 1\% dengan ekstrak kulit kelengkeng (Dimocarpus longan Lour) konsentrasi 80\% lebih efektif dibandingkan konsentrasi $60 \%$ dan $40 \%$ terhadap bakteri Streptococcus mutans.

Sedangkan untuk hasil dari kontrol positif ekstrak kulit kelengkeng konsentrasi 40\%, 60\% dan 80\%, menunjukkan besar zona hambatnya adalah $6,25 \mathrm{~mm} ; 7,10 \mathrm{~mm} ; 8,25 \mathrm{~mm}$. Menurut (Rakariyatham et al., 2020) menunjukkan bahwa ekstrak buah kelengkeng terbukti mempunyai efek dalam pertumbuhan bakteri Streptococcus mutans yang lama dengan diameter zona hambat sebesar $7 \mathrm{~mm}$ dan daya kekuatan hambat yang sedang. Hasil penelitian dari (Oka Adi Parwata and Sastra Dewi, 2008) menyimpulkan bahwa peningkatan konsentrasi suatu zat dapat meningkatkan kandungan senyawa yang terdapat dalam zat tersebut yang berfungsi sebagai antibakteri (Roslizawati et al., 2013).

Kontrol positif lainnya yang digunakan pada penelitian ini ialah nanokitosan $1 \%$, dimana menunjukkan hasil penelitian dengan diameter hambat terhadap pertumbuhan bakteri Streptococcus mutans adalah 7,45 mm. Hasil penelitian yang dilakukan tidak jauh berbeda dari hasil yang didapatkan oleh (Shaimah, 2012), didapatkan bahwa diameter hambat dari formulasi pasta gigi kitosan konsentrasi $1 \%$ memiliki diameter daya hambat lebih tinggi dibandingkan dengan konsentrasi lainnya.

Hasil penelitian juga dapat dilihat terdapat perbedaan antara ketiga grup perlakuan dengan kontrol positif dalam menghambat pertumbuhan bakteri Streptococcus mutans, yaitu adanya peningkatan daya hambat setiap perlakuan dari kontrol positif yang digunakan. Yang menunjukkan bahwa kedua bahan saling mempengaruhi sehingga meningkatkan efek antibakteri dalam menghambat bakteri Streptococcus mutans. Berdasarkan hasil uji Oneway ANOVA dapat dinyatakan bahwa hipotesa dalam penelitian ini dapat diterima yang dimana menunjukkan semakin tinggi diameter hambatnya maka efek sebagai antibakteri dalam menghambat bakteri Streptococcus mutans semakin kuat.

\section{Simpulan Dan Saran}

Berdasarkan penelitian yang telah dilakukan dapat disimpulkan bahwa terdapat efek nanokitosan 1\% yang ditambahkan dengan ekstrak kulit kelengkeng (Dimocarpus longan Lour) pada konsentrasi $40 \%, 60 \%$, dan $80 \%$ dalam memperlambat pertumbuhan bakteri Streptococcus mutans. Terlihat kecenderungan peningkatan daya hambat campuran ekstrak dengan nanokitosan 1\% seiring dengan bertambahnya konsentrasi ekstrak. Daya hambat ekstrak kulit kelengkeng (Dimocarpus longan Lour) 80\% yang ditambahkan dengan nanokitosan $1 \%$ paling efektif dalam menghambat pertumbuhan Streptococcus mutans dibandingkan dengan konsentrasi $40 \%$ maupun $60 \%$.

Perlu dilakukan uji fitokmia secara kuantitatif, terutama menentukan kandungan polifenol dan melakukan penelitian lanjutan untuk membandingkan daya hambat ekstrak kulit dengan biji kelengkeng (Dimocarpus longan Lour) yang dicampurkan nanokitosan 1\% terhadap pertumbuhan bakteri Streptococcus mutans maupun bakteri rongga mulut lainnya.

\section{Daftar Rujukan}

Angela, A. (2005) 'Pencegahan primer pada anak yang berisiko karies tinggi (Primary prevention in children with high caries risk)', Dental Journal (Majalah Kedokteran Gigi), 38(3), p. 130. doi: 10.20473/j.djmkg.v38.i3.p130-134.

Abdassah, M. (2009) 'Nanopartikel dengan gelasi ionik', Farmaka, 15(1), pp. 45-52. 
Bontjura, S., Waworuntu, O. A. and Siagian, K. V. (2015) 'Uji efek antibakteri ekstrak daun leilem ( Clerodendrum minahassae l.) terhadap bakteri streptococcus mutans', Pharmacon Jurnal Ilmiah Farmasi - Unsrat, 4(4).

Citrowati, A. N., Satyantini, W. H. and Mahasri, G. (2019) 'Pengaruh Kombinasi Naoh Dan Suhu Berbeda Terhadap Nilai Derajat Deasetilasi Kitosan Dari Cangkang Kerang Kampak (Atrina pectinata)', Journal of Aquaculture and Fish Health, 6(2), p. 48. doi: 10.20473/jafh.v6i2.11279.

Di, S. and Dangin, S. D. N. (2017) 'Deteksi Gen Gtf-B Streptococcus Mutans Dalam Plak Dengan Gigi Karies Pada', pp. 1-90.

Efektivitas, P. et al. (no date) 'Effectiveness Comparation of Chitosan ( 2-Acetamido-2Deoxy-D-Glucopyranose ) and Nano Chitosan on the Growth of Enterococcus faecalis In Vitro jumlah leukosit dan terkadang dapat disertai mencapai $51 \%$, dengan rincian kandidiasis ditemukan dalam swab vag', pp. 229-240.

Florenly et al. (2015) 'The removal of $\mathrm{Cr}(\mathrm{VI})$ with dimocarpus longan as a low cost biosorbent', Journal of Chemical and Pharmaceutical Research, 7(9), pp. 81-88.

Florenly et al. (2016) 'The effects of $\mathrm{Cr}(\mathrm{VI})$ in the kidney of experimental rats and utilization of longanpeel fruit (Dimocarpuslongan) as renal protector in dentistry', Der Pharma Chemica, 8(16), pp. 144-148.

Fitrianda, M. I. (2016) Digital Digital Repository Repository Universitas Universitas Jember Jember Digital Digital Repository Repository Universitas Universitas Jember diakses tahun 2018.

Fasina, A. S. et al. (2015) ‘No 主観的健康感を中心とした在宅高齢者における健康関連指 標に関する共分散構造分析Title', International Journal of Soil Science, 10(1), pp. 1-14. doi: 10.3923/ijss.2017.32.38.

Gartika, M. and Satari, M. H. (2013) 'Beberapa Bahan Alam sebagai Alternatif Bahan Pencegah Karies', (1)

Hanutami, B. and Budiman, A. (2017) 'Penggunaan Teknologi Nano Pada Formulasi Obat Herbal', Farmaka, 15, pp. 29-39.

Ismiyati, T. et al. (2017) 'Campuran kitosan dengan resin akrilik sebagai bahan gigi tiruan penghambat Candida albicans', Majalah Kedokteran Gigi Indonesia, 3(3), p. 21. doi: $10.22146 /$ majkedgiind.23721.

Konsentrasi, P. et al. (no date) 'Daya Antibakteri Pada Streptococcus Mutans', pp. 47-53.

Oka Adi Parwata, I. and Sastra Dewi, P. (2008) 'Isolasi Dan Uji Aktivitas Antibakteri Minyak Atsiri Dari Rimpang Lengkuas (Alpinia galanga L.)', Jurnal Kimia, 2(2), pp. 100104.

Kawengian, S. A. F., Wuisan, J. and Leman, M. A. (2017) 'Uji daya hambat ekstrak daun serai (Cymbopogon citratus L) terhadap pertumbuhan Streptococcus mutans', e-GIGI, 5(1), pp. 73-79. doi: 10.35790/eg.5.1.2017.14736.

Oktora, L. et al. (2006) 'Pemanfaatan Obat Tradisional Dengan Pertimbangan Manfaat Dan Keamanannya’, Majalah Ilmu Kefarmasian, III(1), pp. 1-7.

Ngajow, M., Abidjulu, J. and Kamu, V. S. (2013) 'Pengaruh Antibakteri Ekstrak Kulit Batang Matoa (Pometia pinnata) terhadap Bakteri Staphylococcus aureus secara In vitro', Jurnal MIPA, 2(2), p. 128. doi: 10.35799/jm.2.2.2013.3121.

Nugraha, A. widya (2008) 'Si Plak Dimana-mana', Mikrobiologi Farmasi Indonesia, (078114061), pp. 1-4. Available at:

https://mikrobia.wordpress.com/2008/05/17/si-plak-dimana-mana/.

Nindya Cahyaningrum, A. (2017) 'Hubungan Perilaku Ibu Terhadap Kejadian Karies Gigi Pada Balita Di Paud Putra Sentosa Relationship of Mother Behavior Against Dental Caries Incidence in Toddler at Putra Sentosa Early Childhood', Departemen Epidemiologi Fakultas Kesehatan Masyarakat Universitas Airlangga, 5(April 2017), pp. 142-151. doi: 10.20473/jbe.v5i2.2017.142-151. 
Qulbi, L. (2017) 'Etnobotani Tumbuhan Berpotensi Obat Karies Gigi pada Masyarakat Kecamatan Besuk Kabupaten Probolinggo dan Uji Aktivitas Antibakteri Streptococcus mutans'.

Rakariyatham, K. et al. (2020) 'Sapindaceae (Dimocarpus longan and Nephelium lappaceum) seed and peel by-products: Potential sources for phenolic compounds and use as functional ingredients in food and health applications', Journal of Functional Foods. Elsevier, 67(September 2019), p. 103846. doi: 10.1016/j.jff.2020.103846.

R. et al. (2013) 'Aktivitas Antibakterial Ekstrak Etanol Dan Rebusan Sarang Semut (Myrmecodia Sp.) Terhadap Bakteri Escherichia coli', Jurnal Medika Veterinaria, 7(2), pp. 91-94. doi: 10.21157/j.med.vet..v7i2.2938.

Rafat, A., Philip, K. and Muniandy, S. (2010) 'Antioxidant potential and phenolic content of ethanplic extract of selected malaysian plants', Research Journal of Biotechnology, 5(1), pp. 16-19.

Rismana, E. et al. (2014) 'Pengujian Aktivitas Antiacne Nanopartikel Kitosan - Ekstrak Kulit Buah Manggis (Garcinia mangostana)', Media Penelitian dan Pengembangan Kesehatan, 24(1), pp. 19-27. doi: 10.22435/mpk.v24i1.3483.1927.

Santi, R. N., Muhtadi and Indrayudha, P. (2011) 'Antibacterial Activity Ethanol Extract of Longan Seed And Peel (Euphoria Longan (Lour.) Steud) AGAINST Escherichia coli AND Staphylococcus aureus And Also Toxicity Against Artemia salina Leach Retno', 12(1), pp. 33-39.

Sharma, M. C. et al. (2009) 'Antimicrobial activity of aqueous extract of Holoptelea integrifolia (Roxb.) leaves: An in vitro study', Pharmacologyonline, 1, pp. 155159.

Shaimah, N. (2012) 'Udang Dan Uji Aktivitas Terhadap Bakteri Streptococcus mutans'.

Suwarda, R. and Maarif, M. S. (2013) 'Pengembangan Inovasi Teknologi Nanopartikel Berbasis Pat Untuk Menciptakan Produk Yang Berdaya Saing', Jurnal Teknik Industri, 3(2), pp. 104-122. doi: 10.25105/jti.v3i2.1572.

Uday Raj, J. et al. (2015) 'Effect of Unipolar Acu-Stim on Muscle Re-Education Following Tendon Transfer - A Case Study', International Journal of Physiotherapy, 2(1), p. 347. doi: 10.15621/ijphy/2015/v2i1/60039.

Wardaniati, R. A. and Setyaningsih, S. (2009) 'Pembuatan Chitosan Dari Kulit Udang Dan Aplikasinya Untuk Pengawetan Bakso', Journal of Colloid and Interface Science, 447, pp. 1-5.

Widayati, N. (2014) 'Factors associated with dental caries in children aged 4-6 years old', Jurnal Berkala Epidemiologi, 2(2), p. 196. doi: 10.20473/jbe.v2i22014.196-205.

Warganegara, E. and Restina, D. (2016) 'Getah Jarak ( Jatropha curcas L . ) sebagai Penghambat Pertumbuhan Bakteri Streptococcus mutans pada Karies Gigi Jarak 's Sap ( Jatropha curcas L . ) as the Growth of Streptococcus mutans Inhibitor in Dental Caries', Majority, 5(3), pp. 1-6.

Wulandari, R., Utami, P. I. and Hartanti, D. (2009) 'Urena lobata', Penapisan Fitokimia Dan Uji Aktivitas Antibakteri Ekstrak Etanol Herba Pulutan (Urena lobata Linn.), 06(01), pp. 1-9. doi: 10.30595/pharmacy.v6i01.396.

Zuniarto, A. A. (2019) 'Sebagai Anti Jamur Terhadap Candida Albicans Testing Activities Of Post-Dental Chitosan From Shrimp Shell Waste As Anti-Fungus Against Candida albicans', 3(1), pp. 1-11. 